\title{
Isolasi dan Identifikasi Bakteri Probiotik Dari Usus Udang Windu (Penaeus monodon) Berdasarkan Sekuens Gen 16S rDNA
}

\author{
SEPRIANTO $^{1,2}$, FELIATRA $^{2}$, TITANIA T NUGROHO ${ }^{3}$ \\ ${ }^{1}$ Program Studi Bioteknologi Universitas Esa Unggul, Jakarta \\ J1. Arjuna Utara No. 29 Kebon Jeruk, Kota Jakarta Barat, DKI Jakarta. 11510 \\ ${ }^{2}$ Jurusan Ilmu Kelautan Universitas Riau, Pekanbaru \\ Jl. HR Subantas Km 12,5 Kampus Bina Widya, Tampan, Pekanbaru Riau, Riau. 28292 \\ ${ }^{3}$ Jurusan Kimia Universitas Riau, Pekanbaru \\ Jl. HR Subantas Km 12,5 Kampus Bina Widya, Tampan, Pekanbaru Riau, Riau. 28292 \\ Email: seprianto@esaunggul.ac.id
}

Received 24 December 2017; Received in revised form 17 January 2018;

Accepted 2 February 2018; Available online 3 February 2018

\begin{abstract}
Probiotics are living microorganisms that have beneficial effect on the host by improving the balance of bacteria in the intestines. This research was aimed to determine the diversity of bacteria that live in digestion of the shrimp and molecular characteristics along with to observe phylogenetic relationships among the bacteria identified based on sequence16S rDNA. The bacteria were isolated from intestine of the Tiger prawn (Penaeus monodon) obtained from fishpond at BBPBAP Jepara. The analyzed result of $16 \mathrm{~S}$ rDNA shown that three bacterial species were potential as probiotic. These bacteria grow well at $\mathrm{pH} 2$ and this indicates one of probiotic bacteria characteristic. Among the three isolates, two isolates i.e. SP2 and SU isolates were phylogenetically closely related to Bacillus bataviensis strain CCGE2059 (EU867382.1) with 97\% homology. While the SWU Isolate is most likely a new species of Caulobacter sp. (AJ227775.1). The SWU isolates were phylogenetically one ancestor with the Chromobacterium violaceum.
\end{abstract}

Keywords: molecular characteristic, PCR, probiotic bacteria, tiger prawn, 16S rDNA

\section{INTISARI}

Probiotik adalah mikroorganisme yang menguntungkan inang dengan memperbaiki keseimbangan bakteri dalam usus. Penelitian ini bertujuan untuk mengetahui keragaman bakteri yang hidup dalam pencernaan udang dengan karakteristik molekuler serta untuk mengamati hubungan filogenetik antar bakteri yang diidentifikasi berdasarkan sekuens 16S rDNA. Bakteri tersebut diisolasi dari usus udang Harimau (Penaeus monodon) yang diperoleh dari kolam ikan di BBPBAP Jepara. Hasil penelitian 16S rDNA menunjukkan bahwa tiga spesies bakteri berpotensi sebagai probiotik. Bakteri tersebut tumbuh dengan baik pada $\mathrm{pH} 2$ dan mengindikasikan salah satu karakteristik bakteri probiotik Diantara ketiga isolat tersebut, dua isolat yaitu Isolat SP2 dan SU secara filogenetik memiliki kekerabatan terdekat dengan Bacillus bataviensis strain CCGE2059 (EU867382.1) dengan homologi 97\%. Sedangkan Isolat SWU kemungkinan besar adalah spesies baru Caulobacter sp (AJ227775.1). Isolat SWU secara filogenetik memiliki satu nenek moyang dengan bakteri Chromobacterium violaceum.

Kata kunci: bakteri probiotik, karakteristik molekuler, PCR, udang windu, 16S rDNA

\section{PENDAHULUAN}

Pemanfaatan probiotik sebagai bahan aditif untuk meningkatkan kualitas pakan yang baik sangat dibutuhkan dalam penyerapan nutrisi. Selain dapat meningkatkan ketersediaan lemak dan protein bagi ternak, probiotik juga mampu mencegah dan mengobati penyakit tertentu (Nur $d k k ., 2015$ ), 
meningkatkan kekebalan, mencegah perkembangan bakteri patogen dalam usus, sehingga dapat mendukung kesehatan hewan (Gaggia et al., 2010). Penambahan probiotik pada pakan ayam dapat memberikan pengaruh terhadap metabolit darah ayam yang dapat dijadikan sebagai sistem ketahanan tubuh terhadap penyakit (Bijanti $d k k$., 2009). Penambahan probiotik juga dapat memiliki kemampuan adhesi, memproduksi bacteriocin (antimicrobial peptide) dan dapat memberikan imunostimulasi pada hewan tersebut (Cherif et al., 2001). Selanjutnya Verschere et al., (2000) menyatakan bahwa probiotik sebagai penambah mikroba hidup yang memiliki pengaruh menguntungkan bagi komunitas mikroba lingkungan hidupnya.

Skrining bakteri menggunakan teknik sekuens 16S rDNA merupakan suatu teknik modern dalam mengidentifikasi suatu spesies organisme. Teknik ini dilakukan dengan menganalisa struktur atau susunan basa DNA yang terdapat di daerah $16 \mathrm{~S}$ rDNA. Amplifikasi gen 16S rDNA dapat menentukan spesies bakteri dalam ekologi bakteri secara metagenom (Vetrovsky and Baldrian, 2013). Seiring semakin berkembangnya dunia bioteknologi, usaha untuk menentukan jenis spesifik bakteri yang bersifat probiotik pada udang secara tepat dan efisien sangat diperlukan, untuk dimanfaatkan sebagai efisiensi pemanfaatan pakan pada udang baik dari segi membantu daya cerna udang maupun enzim yang dihasilkan bakteri itu sendiri.

Saat ini, banyak ahli taksonomi mikrobiologi mengakui bahwa studi molekuler, terutama analisis asam nukleat merupakan metode terbaik dan terpercaya untuk menandakan spesies dan menentukan hubungan antara organisme yang berbeda. Salah satu teknologi terkini yang mampu mengidentifikasi spesies bakteri probiotik adalah teknik sekuens $16 \mathrm{~S}$ rDNA. Teknik ini merupakan teknik yang relatif baru yang belakangan sering diterapkan karena dapat dibandingkan dengan basis data di GenBank untuk mengetahui kemiripan homologi DNA dengan bakteri yang sejenis. Sekuen gen 16S rDNA dari mikroorganisme yang baru ditemukan dapat dibandingkan dengan pustaka sekuen 16S rDNA dari mikroorganisme lain melalui program pelacakan Database Basic Local Alignment Search Tool (BLAST) (Altschul et al., 2009). Untuk itu peneliti tertarik menggunakan teknik ini, selain cepat dan akurat dalam mengidentifikasi bakteri, juga dapat digunakan untuk melihat biodiversitas bakteri probiotik.

Penelitian ini bertujuan untuk mengetahui keberagaman bakteri yang terdapat dalam usus udang windu (Penaeus monodon) terutama bakteri probiotik dan melihat karakteristik molekuler serta melihat kekerabatan terdekat dari bakteri yang teridentifikasi.

\section{METODE}

Pengambilan Sampel dan Isolasi Bakteri. Sebanyak 5 ekor sampel udang dicuci dan dibedah secara aseptik kemudian digerus pada bagian saluran pencernaan (usus dan lambung). Hasil gerusan diencerkan dalam larutan trisalt (larutan fisiologis) pada $\mathrm{pH} 2$ yang disesuaikan dengan $\mathrm{pH}$ lambung dengan tujuan hanya bakteri probiotik yang dapat tumbuh dan berkembang pada $\mathrm{pH}$ tersebut. Pengenceran (perbandingan 1:9). Masingmasing pengenceran diambil sebanyak $0,1 \mathrm{ml}$ untuk dilakukan penanaman bakteri pada media padat NA (Nutrient Agar) dengan kondisi $\mathrm{pH}$ 2. Setiap koloni yang diperoleh dibuat tiga ulangan pemurnian untuk mendapatkan koloni yang tunggal dan dilanjutkan untuk pengujian secara biokimia.

\section{Identifikasi Bakteri dengan Uji} Biokimia. Pengamatan bakteri terpilih diidentifikasi secara morfologi seperti pengamatan bentuk sel, warna koloni, ukuran koloni dan tipe koloni. Selain itu, pengujian biokimia juga dilakukan dalam uji bakteri. Uji morfologi maupun uji biokimia berdasarkan buku panduan identifikasi Cowan dan Steel's yang meliputi uji pewarnaan Gram, pengamatan bentuk sel, uji motilitas, sifat aerobik dan anaerobik, uji katalase, uji oksidase, glukosa acid, karbohidrat, kemampuan tumbuh pada kosentrasi $\mathrm{NaCl}$ yang berbeda (10\% dan 6\%), mereduksi nitrat, indol, ONPG, VP (voges-Prokauer), hidrolisis (starch, urea, casein), Uji gula-gula (glukose, celibiose, galaktose, rafinose, salicin, xylose), 
kemampuan tumbuh pada suhu $37^{\circ} \mathrm{C}$ dan $50^{\circ} \mathrm{C}$, uji citrat, gas dari glukosa dan resistensi (0/29) (Cowan dan Steel's, 2004).

Ekstraksi DNA Bakteri. Metode ekstraksi DNA bakteri menggunakan metode Phenol - Cloroform. Kultur cair bakteri dimasukkan ke dalam mikrotube $1,5 \mathrm{ml}$ dan disentrifugasi dengan kecepatan $12.000 \times \mathrm{g}$ selama 5 menit. Supernatan dibuang, kemudian ditambahkan $300 \mu \mathrm{l}$ Deionized Water, $30 \mu \mathrm{l}$ proteinase, $30 \mu \mathrm{l}$ RNAse, $30 \mu \mathrm{l}$ SDS 1\%. Selanjutnya sampel diinkubasi selama 15 menit dengan suhu $37^{\circ} \mathrm{C}$ kemudian ditambahkan $400 \mu \mathrm{l}$ phenol jenuh, vortek selama 1 menit. Selanjutnya, sampel disentrifugasi dengan kecepatan $12.000 \times \mathrm{g}$ selama 5 menit pada suhu ruangan. Supernatan dipindahkan ke dalam mikrotube yang baru. Kemudian ditambahkan $400 \mu \mathrm{l}$ choloroformisoamyl alkohol dan divortek selama 30 detik. Sampel disentrifugasi dengan kecepatan $12.000 \times$ g selama 5 menit pada suhu ruangan dan sebanyak $300 \mu$ l supernatan dipindahkan ke dalam mikrotube baru. Selanjutnya ditambahkan $30 \mu 1(3 \mathrm{M})$ sodium acetat dan $750 \mu 1$ etanol absolut dan divortek. Sentrifugasi dengan kecepatan $12.000 \times \mathrm{g}$ selama 5 menit dalam suhu ruangan. Supernatan dibuang, tambahkan $1500 \mu 175 \%$ etanol. Kemudian sentrifugasi dengan kecepatan $12.000 \times$ g selama 2 menit. Sebanyak $1200 \mu \mathrm{l}$ ethanol absolut ditambahkan Sentrifugasi dengan kecepatan 12.000×g selama 2 menit. Buang ethanol dan keringkan dalam desikator selama 10 menit. Setelah kering ditambahkan $200 \mu \mathrm{l}$ akuades steril. DNA disimpan pada suhu $4^{\circ} \mathrm{C}$ dan siap digunakan.

Amplifikasi Polymerase Chain Reaction (PCR). Amplifikasi gen 16S rDNA menggunakan primer universal 24F (5'AGAGTTTGATCCTGGCT-3') dan 1540R (5'AAGGAGGTGATCCAGCCGCA3') (Lane, 1991) dengan total volume 25 yang mengandung $1 \mu \mathrm{L}$ DNA genom, $12.5 \mu \mathrm{L} P C R$ Taq Green Master Mix (Thermo Scientific), 1

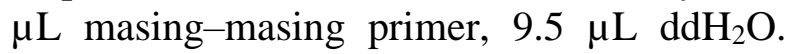
Amplifikasi PCR dilakukan sebanyak 30 siklus menggunakan Gene Amp ${ }^{\circledR}$ PCR System 9700 (Applied Biosystem). Untuk satu kali siklus terdiri dari tiga tahapan yaitu denaturasi (denaturation), penempelan (annealing), dan pemanjangan (extension). Tahap predenaturasi dilakukan selama 7 menit pada suhu $94^{\circ} \mathrm{C}$ sebanyak satu kali, tahap denaturasi $94^{\circ} \mathrm{C}$ selama 1 menit, tahap penempelan (annealing) primer pada suhu $50 \mathrm{C}$ selama 30 detik perpanjangan rantai DNA (extension) pada suhu $72{ }^{\circ} \mathrm{C}$ selama 1 menit. Pada siklus terakhir dilakukan pemanjangan rantai lebih lama pada suhu $72{ }^{\circ} \mathrm{C}$ selama 5 menit (Liu et al., 2015).

Elektroforesis dan Purifikasi Hasil PCR. Hasil PCR diimigrasikan ke dalam gel agarose $1,5 \%$ pada kondisi 100 volt 40 menit. Marker DNA $1 \mathrm{~Kb}$ digunakan sebagai penanda. Pewarnaan gel menggunakan ethidium bromide $(10 \mu \mathrm{g} / \mathrm{mL})$ selama 10 menit, selanjutnya dimasukan ke dalam akuades selama 5 menit untuk pencucian ethidium bromide yang masih menempel pada gel. Gel yang berisi fragmen DNA divisualisasikan dengan menggunakan $U V$ Trans Illuminator dan didokumentasikan menggunakan $\mathrm{Gel}$ Documentation System Digibox Camera.

Analisis Sekuensing. Hasil PCR disekuen menggunakan Genetic Analyzer (Applied Biosystem) dan hasil sekuen dianalisis menggunakan software bioedit, DNAstar, ClustalX dan MEGA 6. Hasil analisis dibandingkan dengan sekuen 16S rRNA data GenBank pada situs (http://www.ncbi.nlm.nih.gov) dengan menggunakan perangkat lunak BLASTn (Basic Local Alignmet Search Tools for nucleotide) dengan mengacu pada galur galur terdekat yang tersimpan di GenBank (Altschul et al., 2009). Analisis hubungan kekerabatan terdekat berdasarkan pohon filogenetik menggunakan MEGA 6 dengan pengulangan 1000 kali bootstrap (Tamura et al., 2013).

\section{HASIL}

Isolasi bakteri probiotik dari usus udang menggunakan medium agar NA (Nutrient Agar) dengan kondisi pH 2 yang merupakan indikator utama bakteri probiotik. Dari hasil isolasi terdapat empat isolat murni yang berbeda yang dilihat dari ciri-ciri 
morfologinya. Isolat tersebut dengan kode SP2, SU, SWU dan TU.

Dari keempat isolat tersebut, isolat TU merupakan bakteri vibrio, karena dapat tumbuh pada media TCBS yang merupakan media selektif untuk vibrio. Serangkaian uji biokimia berdasarkan acuan buku Cowan dan Steel's (2004) pada masing-masing isolat menunjukan hasil yang berbeda-beda (Tabel 1).

Tabel 1. Hasil Uji Biokimia Masing-Masing Isolat

\begin{tabular}{|c|c|c|c|}
\hline \multirow{2}{*}{ Uji Biokimia } & \multicolumn{3}{|c|}{ Kode Isolat bakteri } \\
\hline & $\mathbf{S P}^{2}$ & SU & SWU \\
\hline Gram & + & + & - \\
\hline Bentuk & Batang & Batang & Batang \\
\hline Ketahanan Asam & - & - & $\mathrm{V}$ \\
\hline Spora & + & + & $\mathrm{V}$ \\
\hline Posisi dan bentuk spora & VX & VTX & $\mathrm{V}$ \\
\hline Panjang cell $>3 \mu \mathrm{m}$ & + & - & $\mathrm{V}$ \\
\hline Motilitas & + & + & + \\
\hline Aerobik & + & + & + \\
\hline An aerobik & $+^{\mathrm{F}}$ & $+^{\mathrm{F}}$ & $+^{\mathrm{F}}$ \\
\hline Katalase & + & + & + \\
\hline Oksidase & + & - & + \\
\hline Glukosa & + & - & + \\
\hline Karbohidrat (OF) & $\mathrm{NC}$ & $\mathrm{NC}$ & + \\
\hline Pertumbuhan 10\% NaCl: & + & + & $\mathrm{V}$ \\
\hline Pertumbuhan $6 \% \mathrm{NaCl}$ & $\mathrm{V}$ & $\mathrm{V}$ & - \\
\hline Degradasi Nitrat & + & - & + \\
\hline Indol & - & - & + \\
\hline ONPG & - & - & $\mathrm{V}$ \\
\hline $\mathbf{V P}$ & + & - & - \\
\hline Hidrolisis of : & & & \\
\hline Starch & + & - & V \\
\hline Urea & - & - & V \\
\hline Casein & + & + & $\mathrm{V}$ \\
\hline Uji Gula - Gula & + & - & $\mathrm{V}$ \\
\hline Glucosa & _- & _- & $\mathrm{V}$ \\
\hline Celibiosa & _- & _- & $\mathrm{V}$ \\
\hline Galactosa & _- & - & $\mathrm{V}$ \\
\hline Rafinosa & - & - & $\mathrm{V}$ \\
\hline Salicin & - & - & $\mathrm{V}$ \\
\hline Xylose & _- & _- & V \\
\hline Pertumbuhan $50{ }^{\circ} \mathrm{C}$ & - & + & $\mathrm{V}$ \\
\hline Pertumbuhan $37^{\circ} \mathrm{C}$ & $\mathrm{V}$ & $\mathrm{V}$ & + \\
\hline Citrat & + & + & $\mathrm{V}$ \\
\hline Gas Glukosa & $\mathrm{V}$ & $\mathrm{V}$ & - \\
\hline Resistens & & & \\
\hline $0 / 12910 \mu \mathrm{g}$ & V & $\mathrm{V}$ & - \\
\hline $0 / 129150 \mu \mathrm{g}$ & V & $\mathrm{V}$ & - \\
\hline
\end{tabular}

Ket: VX: Central-Oval (ellipoidal); VTX: Central/Termonal Oval; +F: Fakultatif anaerobik; F: Fermentatif; NC: tidak ada perubahan; V: Tidak dilakukan analisis 
Hasil visualisasi DNA yang sudah diamplifikasi dengan menggunakan primer universal $24 \mathrm{~F}$ dan $1540 \mathrm{R}$ dielektroforesis untuk menunjukkan ukuran fragmen DNA dengan menggunakan gel agarose (Gambar 1).

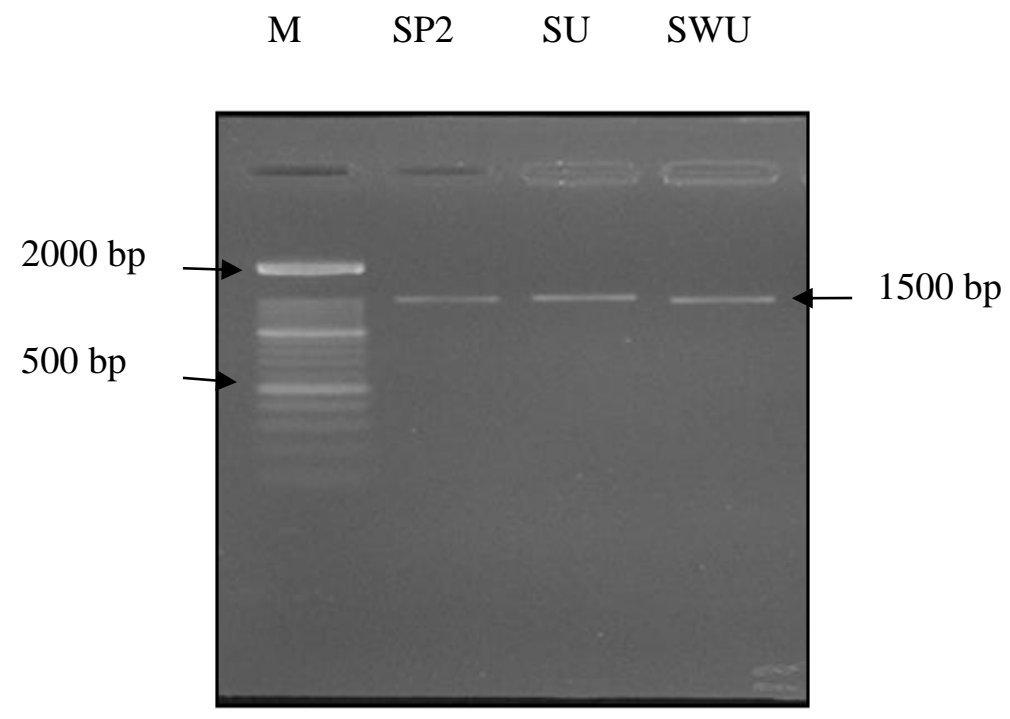

Gambar 1. Hasil amplifikasi DNA- PCR universal pada gel agarose

\section{PEMBAHASAN}

Hasil uji biokimia masing-masing isolat. Isolat SP2 mempunyai ciri-ciri morfologi bentuk koloni bulat (sirkular), warna koloni krem, sel berbentuk batang panjang dan besar (basil), mempunyai dinding yang tebal (gram positif), posisi spora pada sentral tubuh, panjang sel besar dari $3 \mu \mathrm{m}$, bersifat motil, bersifat aerob dan anaerob fakultatif, mampu menghasilkan enzim katalase dan oksidase, glukosa acid positif, mampu tumbuh pada konsentrasi $\mathrm{NaCl} 10 \%$, dapat mereduksi nitrat, tidak mampu membentuk indol dari molekul triptofan, ONPG negatif, netral dari asam organik yang dihasilkan dari metabolisme glukosa, tidak mampu menghidrolisa urea menjadi amoniak, mampu menghancurkan casein, fermentasi gula-gula hanya glukosa yang dapat difermentasi, tidak mampu tumbuh pada suhu $50{ }^{\circ} \mathrm{C}$ dan bakteri mampu memanfaatkan citrat sebagai sumber karbon untuk proses metabolisme.

Isolat SU mempunyai ciri-ciri morfologi dengan bentuk koloni bulat (sirkular), warna koloni krem transparan, sel berbentuk batang panjang dan kecil (basil), mempunyai dinding yang tebal (gram positif), posisi spora pada sentral tubuh, panjang sel kecil dari $3 \mu \mathrm{m}$, bersifat motil, bersifat aerob dan anaerob fakultatif, mampu menghasilkan enzim katalase, tidak menghasilkan enzim oksidase, mampu tumbuh pada konsentrasi $\mathrm{NaCl} 10 \%$, tidak dapat mereduksi nitrat, tidak mampu membentuk indol dari molekul triptofan, ONPG negatif, netral dari asam organik yang dihasilkan dari metabolisme glukosa, tidak mampu menghidrolisa urea menjadi amoniak, mampu menghancurkan casein, tidak dapat fermentasi gula-gula, mampu tumbuh pada suhu $50^{\circ} \mathrm{C}$ dan mampu memanfaatkan sitrat untuk proses metabolisme.

Isolat SWU mempunyai ciri-ciri morfologi sebagai berikut : bentuk koloni tepian berakar (rizoid), warna koloni putih transparan, sel berbentuk batang pendek (basil), mempunyai dinding yang tipis (gram negatif), tidak berspora, bersifat motil, bersifat aerob dan anaerob fakultatif, mampu menghasilkan enzim katalase dan oksidase, tidak mampu tumbuh pada konsentrasi $\mathrm{NaCl}$ $6 \%$, dapat mereduksi nitrat, tidak mampu membentuk indol dari molekul triptofan, netral dari asam organik yang dihasilkan dari metabolisme glukosa, mampu tumbuh pada suhu $37^{\circ} \mathrm{C}$, menghasilkan gas, dan bersifat 
sensitif terhadap antibiotik. Identifikasi ini hanya bersifat sementara karena hasil pengujian biokimia ini masih harus disesuaikan dengan hasil dari teknik sekuensing 16S rDNA dengan penelusuran dari program BLAST yang berbasis data yang ada di GenBank.

\section{Hasil amplifikasi DNA-PCR universal} pada gel agarose. Gambar 1 menunjukkan bahwa semua isolat menghasilkan pita tunggal yang terlihat jelas dengan ukuran antara 13001500 bp (base pair) sesuai dengan ukuran amplifikasi primer yang digunakan dengan perbandingan menggunakan DNA $1 \mathrm{~Kb}$
Ladder. Besarnya ukuran ini sesuai dengan ukuran yang diharapkan dari gen-gen $16 \mathrm{~S}$ rDNA bakteri yaitu 1300-1500 bp (Marchesi et al., 1998).

Pensejajaran sekuen gen 16S rDNA dengan BLAST. Sistem BLAST melalui situs http//www.ncbi.nlm.nih.gov/ dapat mencari nama spesies, persentase homologi DNA hasil sekuen dengan basis data yang sudah ada di GenBank. Sedangkan hasil identifikasi masing -masing isolat bakteri dari hasil BLAST diambil berdasarkan homologi tertinggi yang mempunyai kekerabatan terdekat dengan bakteri yang ada di GenBank (Tabel 2).

Tabel 2. Hasil MEGABLAST Sekuen Gen 16S rDNA

\begin{tabular}{ccccc}
\hline Isolat & BLAST & $\begin{array}{c}\text { Accession } \\
\text { Number }\end{array}$ & $\begin{array}{c}\text { Query } \\
\text { Coverage }\end{array}$ & $\begin{array}{c}\text { Max } \\
\text { Ident }\end{array}$ \\
\hline SP2 & B. bataviensis CCGE2059 & EU867382.1 & $100 \%$ & $97 \%$ \\
\hline SU & B. bataviensis CCGE2059 & EU867382.1 & $99 \%$ & $97 \%$ \\
\hline SWU & Caulobacter sp. WTH01 & AJ227775.1 & $98 \%$ & $95 \%$ \\
\hline
\end{tabular}

Hasil pensejajaran sekuen gen 16S rDNA dengan BLAST (Tabel 2) menunjukkan bahwa ketiga isolat bakteri dengan kode SP2 teridentifikasi sebagai Bacillus bataviensis CCGE2059 dengan homology 97\% dengan query coverage $100 \%$ dengan top score tertinggi (2159). Isolat SU teridentifikasi sebagai Bacillus bataviensis CCGE2059 dengan homologi $97 \%$ tetapi query coverage hanya 99\% dengan top score tertinggi (2126). Sedangkan isolat SWU teridentifikasi sebagai Caulobacter sp yang berdasarkan penelusuran BLAST top score tertinggi bakteri ini dengan homology $95 \%$ dengan query coverage $98 \%$. Hagström et al. (2000) menyatakan bahwa bakteri yang mempunyai persamaan sekuen 16S rRNA lebih besar dari 97\% adalah spesies yang sama. Sedangkan persamaan sekuen antara 93-97\% dapat mewakili identitas pada tingkat genus tetapi berbeda pada tingkat spesies. Homologi sekuen 16S rRNA dari masing-masing isolat bakteri dengan sekuens 16S rRNA dari database GenBank dapat diketahui bahwa tidak ada sekuen 16S rRNA bakteri yang identik.
Analisis Pohon Filogenetik. Pada dasarnya pembentukan pohon filogenetik tersebut dilakukan dengan melihat kesamaan yang ada pada genetik organisme yang dibandingkan. Semakin tinggi tingkat kesamaan genetiknya, maka semakin dekat pula hubungan evolusi dan kekerabatannya. Organisme-organisme yang dibentuk pohon filogenetiknya harus mempunyai kemiripan dari segi genetiknya. Metode ini didasarkan proses urutan nukleotida gen 16S rDNA. Analisis filogenetik menggunakan metode Neighbour Joining yaitu pasangan nukleotida yang mengalami perubahan terkecil diantara sekuen yang telah dibandingkan. Nilai jarak dilambangkan oleh garis skala yang menunjukkan jumlah substitusi nukleotida untuk tiap posisi sekuen. Nilai jarak sebesar 0.001 pada hasil konstruksi pohon filogenetik menunjukkan rendahnya substitusi nukleotida pada sekuen 16S rRNA. Berdasarkan analisis pohon filogenetik masing-masing isolat yang mana isolat SP2 dan Isolat SU sama-sama memiliki kekerabatan terdekat dengan Bacillus bataviensis CCGE2059 (Gambar 2). 


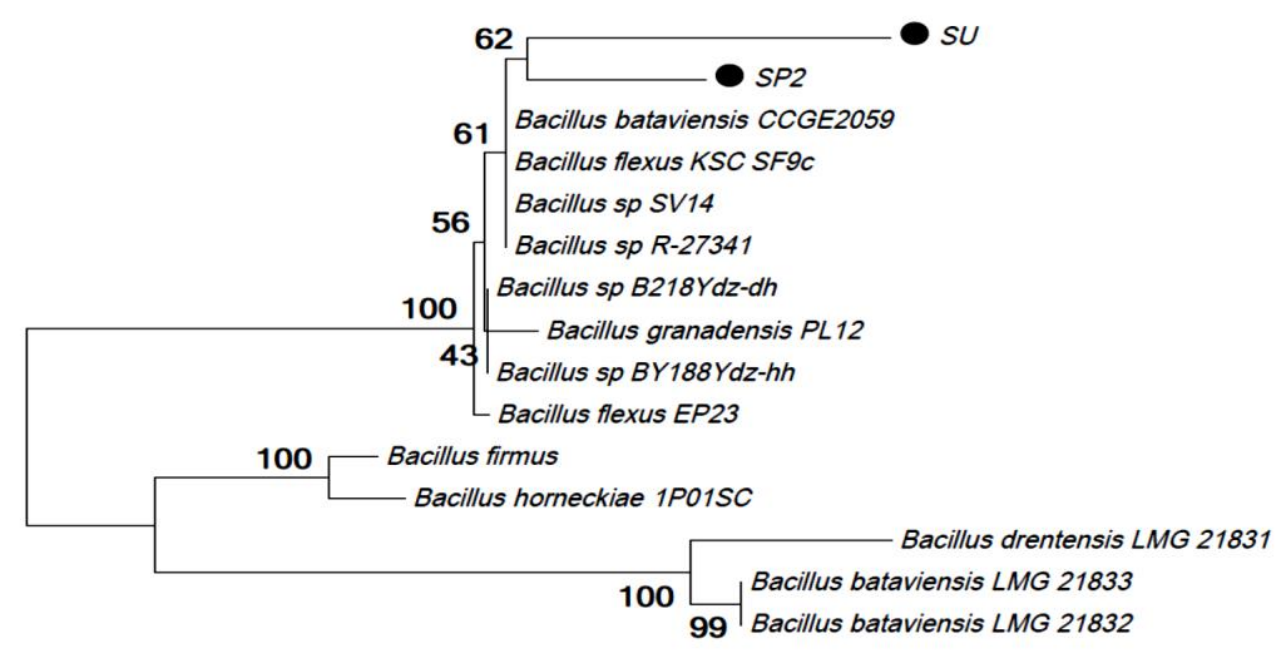

$\overrightarrow{0.001}$

Gambar 2. Pohon filogenetik (kladogram) isolat SP2 dan SU dengan beberapa spesies Bacillus berdasarkan hasil BLAST dan publikasi jurnal internasional (Heyman et al., 2004)

Gambar 2 menunjukkan Isolat $\mathrm{SP}^{2}$ mempunyai kesamaan yang signifikan dengan isolat SU, hal ini dapat dilihat dari hasil filogenetik yang mempunyai kekerabatan dekat dengan terbentuknya satu titik percabangan dengan Bacillus bataviensis strain CCGE2059. Persentase kesamaan dari kedua isolat dapat dilihat di hasil BLAST dengan identitas $95 \%$ dengan perbedaan basa nukleotida 43 basa (3\%). Tetapi secara keseluruhan dari hasil penelusuran BLAST mempunyai perbedaan Query coverage dan top score yang dimiliki Isolat SU lebih rendah dibandingkan dengan isolat $\mathrm{SP}^{2}$. Perbedaan ini juga dapat ditunjukkan dengan nilai bootstrap sebesar 620x dari 1000x bootstrap. Rendahnya nilai tersebut kemungkinan disebabkan kurang tepat dan kurang banyak spesies acuan dari strain-strain yang ada. Ketersediaan data di GenBank sangat menentukan hasil penelusuran sesuai dengan yang ditargetkan sehingga ketika pelacakan akan dicari kekerabatan terdekat dari bakteri yang telah terdaftar di GenBank. Kemungkinan sangat besar bahwa isolat $\mathrm{SP}^{2}$ dan $\mathrm{SU}$ adalah $B$. bataviensis yang ditunjukkan oleh nilai bootstrap yang cukup baik yaitu munculnya percabangan hanya 610x dari 1000x bootstrap (Gambar 2). Metode Bootstrap digunakan untuk menguji keakuratan suatu titik cabang pohon filogenetik. Stabilitas pengelompokkan (robustness) diperhitungkan menggunakan bootstrap dengan 1000 kali ulangan (Xi et al., 2015).

Bakteri yang di temukan dari usus udang windu (Penaeus monodon) yaitu Bacillus sp. dari isolat SP2 dan SU dapat disimpulkan adalah Bacillus bataviensis. Menurut Heyman et al., (2004) dari hasil penelitiannya tentang bakteri yang diisolasi dari rumput yang terdapat di sepanjang padang rumput Atlor di Belanda menemukan bakteri yang dominan dari spesies Bacillus diantaranya $B$. bataviensis strain LMG 21833, B. bataviensis strain LMG 21832. Hal ini dapat dianalisis bahwa keberadaan suatu spesies yang sama dapat ditemukan pada kondisi lingkungan yang berbeda karena bakteri termasuk organisme yang cepat beradaptasi dengan kondisi fisiologis yang berbeda, masa dorman yang cukup panjang dan kemungkinan membentuk endospora sehingga dapat bertahan dalam kondisi lingkungan yang ekstrim. 


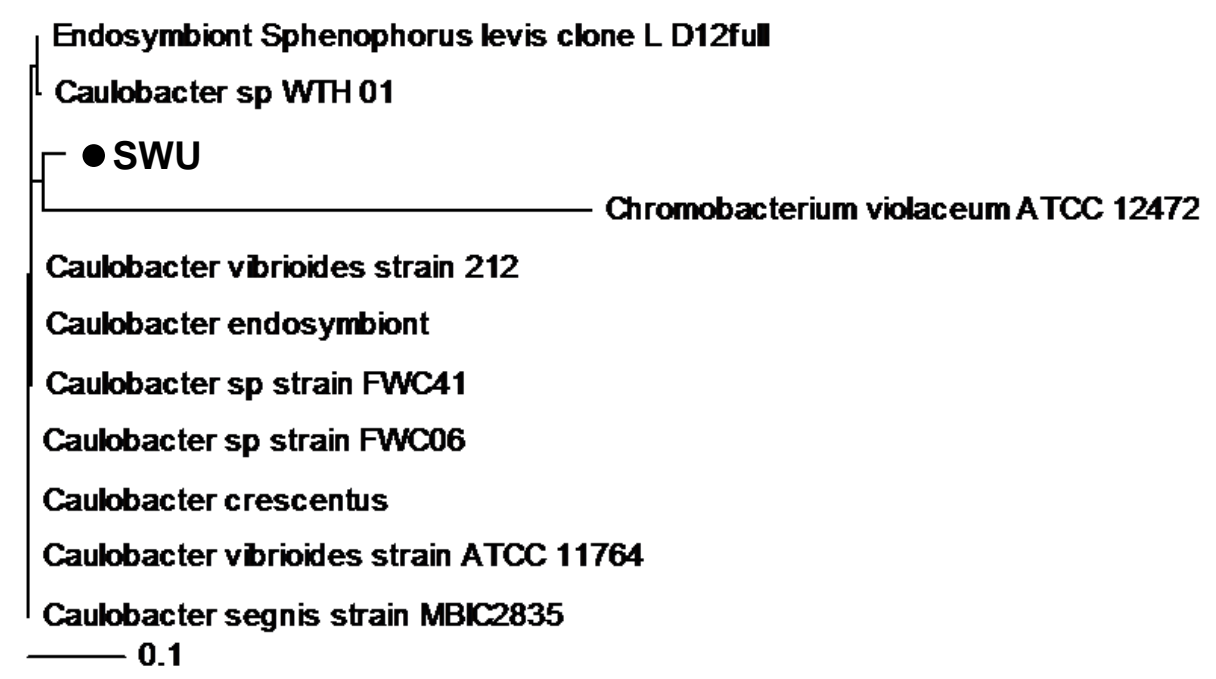

Gambar 3. Pohon filogenetik isolat SWU dengan beberapa spesies Caulobacter berdasarkan hasil BLAST dan publikasi jurnal internasional (Yarza et al., 2008)

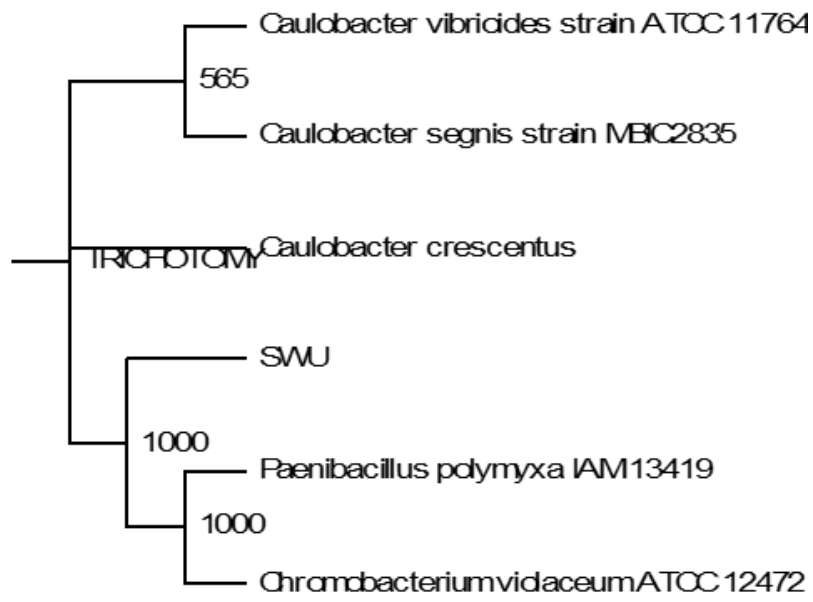

Gambar 4. Kladogram dengan Paenibacillus polymyxa IAM 13419 sebagai kelompok luar

Gambar 3 menunjukkan bahwa SWU sangat berbeda dengan Chromobacterium violaceum, yakni perbedaan nukleotidanya lebih dari 0.1 nukleotida (jarak evolusi 0,1 nukleotida, berarti untuk setiap sepuluh nukleotida terdapat 1 perbedaan). Dengan demikian, sebenarnya Chromobacterium violaceum dapat dianggap sebagai outgroup. Ini lebih diperjelas dengan kladogram Gambar 4 yang menyertakan outgroup Paenibacillus polymyxa IAM 13419. Chromobacterium violaceum ternyata telah berevolusi lebih jauh dari SWU dibandingkan Paenibacillus polymyxa IAM 13419, yang merupakan Genus yang berbeda. Hal ini diperkuat dengan kladogram pada Gambar 4 bahwa percabangan SWU dengan Chromobacterium violaceum dan Paenibacillus polymyxa terjadi 1000x dari 1000 bootstrap, berarti divergensi ini nyata, dan SWU tidaklah sama dengan Chromobacterium violaceum maupun Paenibacillus polymyxa, meskipun memiliki satu nenek moyang bersama. Secara evolusi SWU lebih dekat dengan genus Caulobacter sp.

Gambar 3 menunjukkan kedekatan evolusi SWU dengan Caulobacter sp. lebih besar dari pada dengan Chromobacterium violaceum. Sulit untuk mengatakan bahwa SWU salah satu spesies dari adalah 
Caulobacter yang telah dilaporkan. Hal ini disebabkan SWU telah berevolusi lebih jauh dibandingkan Caulobacter sp. yang telah dilaporkan. Kerabat terdekatnya adalah Caulobacter sp. strain WTH1, dan endosymbiont Sphenophorus levis, dan telah mengalami divergensi dengan kemungkinan percabangan tinggi (Gambar 3) Kemungkinan sekali SWU adalah spesies baru Caulobacter. Kemungkinan ini masih harus dibuktikan dengan uji biokimia yang lebih mendalam dan uji genetik menggunakan marker DNA lain yang spesifik untuk Caulobacter.

Bakteri dari genus Bacillus telah banyak diteliti manfaatnya, baik yang berasosiasi dalam maupun luar tubuh organisme lain terutama ikan. Bacillus merupakan bakteri probiotik yang sudah banyak dikomersilkan dalam bentuk produk pakan probiotik yang ditebar pada kolam atau tambak. Bakteri ini dapat menghambat pertumbuhan bakteri patogen seperti bakteri Vibrio sp. yang berada di perairan (Vinoj et al., 2014). Selain dapat meningkatkan berat badan dalam proses digesti atau penyerapan nutrien dan juga dapat meningkatkan kesehatan ikan (Gaggia et al., 2010). Dalam penelitian ini tidak memperhatikan mekanisme kerja probiotik dan nutrien atau enzim yang dapat meningkatkan proses digesti.

\section{KESIMPULAN}

Bakteri yang diisolasi dari usus udang windu (Penaeus monodon) berdasarkan analisis gen 16S rDNA diperoleh 3 spesies bakteri berbeda yang berpotensi sebagai probiotik. Diantara ketiga isolat tersebut, dua isolat yaitu Isolat SP2 dan SU secara filogenetik memiliki kekerabatan terdekat dengan Bacillus bataviensis strain CCGE2059 (EU867382.1) dengan homologi 97\%. Sedangkan Isolat SWU kemungkinan besar adalah spesies baru Caulobacter sp (AJ227775.1). Isolat SWU secara filogenetik memiliki satu nenek moyang dengan bakteri Chromobacterium violaceum.

\section{UCAPAN TERIMA KASIH}

Penulis mengucapkan terima kasih kepada BBPBAP Jepara yang telah memfasilitasi penelitian ini serta IM-HERE Project Scholarship yang telah mendanai penelitian ini sampai selesai.

\section{DAFTAR PUSTAKA}

Altschul SF, Gertz EM, Agarwala R, Schäffer AA, Yu YK. 2009. PSI-BLAST: psedocount and the minimum description length principle. Nucleic Acid Res. vol 37(3):

815-824. https://doi.org/10.1093/nar/gkn981.

Bijanti R, Wahjuni RS. Yuliani MGA. 2009. Suplementasi Probiotik Pada Pakan Ayam Komersial Terhadap Produk Metabolik Dalam Darah Ayam. J. Penelit. Med. Eksakta. vol 8(3): 178-184.

Cherif A, Ouzari H, and Deffonichio. 2001. Thuricin 7: A Novel Bacteriocin Produced by Bacillus sp BMGI a New Strain From Oil. Letter in Applied Microbiology. vol 32(4): 243-247.

Cowan and Steel's. 2004. Manual for the Identification of Medical Bacteria. $3^{\text {rd }}$ Edition. UK: Cambriage University Press

Gaggia F, Mattarelli P, Biavati B. 2010. Probiotics and Prebiotics in Animal Feeding For Safe Food Production. International Journal of Food Microbiology. vol 141: S15-S28. https://doi.org/10.1016/j.ijfoodmicro.201 $\underline{0.02 .031}$.

Hagström A, Pinhassi J, Zweiefel UL. 2000. Biogeoghraphycal Diversity Among Marine Bacterioplankton. Aquatic Microbial Technology. vol 21: 231-244.

Heyman J. Vanparys B, Logan NA, Balcaen A, Rodríguez-Díaz M, Felske A, De Vos P. 2004. Bacillus novalis sp, Nov., Bacillus vireti sp. Nov., Bacillus soli sp. Nov., Bacillus bataviensis sp nov., and Bacillus dretensis sp., From The Drentse a Grasslands. International Journal of Sytematic and Evolutionary Microbiology. vol 54: 4757. https://doi.org/10.1099/ijs.0.02723-0. Lane DJ. 1991. 16S/23S rRNA Sequencing. In Stackebrandt, E. and Goodfellow, M., Eds., Nucleic Acid Techniques in Bacterial Systematic. New York: John Wiley and Sons. pp 115-175. 
Liu D, Du L, Yu J, Li L, Ai Q, Feng J, Song C. 2015. 16S rDNA PCR-DGGE and sequencing in the diagnosis of neonatal late-onset septicemia. Mol Med Rep. vol 12(4):6346-52. https://doi.org/10.3892/mmr.2015.4131.

Marchesi JR, Sato T, Weightman AJ, Martin TA, Fry JC, Hiom SJ, Wade WG. 1998. Design and evaluation of useful bacterium-spesific PCR primers that amplify genes coding for bacterial $16 \mathrm{~S}$ rRNA. Appl Environ Microbiol. vol 64(2): 795-799.

Nur F, Hafsan, Wahdiniar A. 2015. Isolasi Bakteri Asam Laktat Berpotensi Probiotik Pada Dangke, Makanan Tradisional dari Susu Kerbau di Curio Kabupaten Enrekang. Biogenesis. vol 3(1): 60-65. https://doi.org/10.24252/bio.v3i1.568.

Yarza P, Richter M, Peplies J, Euzeby J, Amann R, Schleifer KH, Ludwig W, Glöckner FO, Rosselló-Móra R. 2008. The All-Species Living Tree Project: a 16S rRNA-based phylogenetic tree of all sequenced type strains. System. Appl. Microbiol. $\quad$ vol 31(4): 241-250. https://doi.org/10.1016/j.syapm.2008.07. $\underline{001}$.

Tamura K, Stecher G, Peterson D, Filipski A, Kumar S. 2013. MEGA 6: Molecular Evolutionary Genetics Analysis Version 6.0. Molecular Biology and Evolution. vol
30(12):

2725-2729. https://doi.org/10.1093/molbev/mst197.

Verschere L, Rombaut G, Sorgeloos P, Verstraete W. 2000. Probiotic bacteria as biological control agents in aquaculture. Microbiol Mol Biol Rev. vol 64(4): 655671.

Vinoj G, Vaseeharan B, Thomas S, Spiers AJ, Shanthi S. 2014. Quarum-Quenching activity of The AH-Lactonase from Bacillus licheniformis DAHBI Inhibits Vibrio Biofilm Formator In Vitro and Reduces Shimp Intestinal Colonisation and Mortality. Marine Biotechnology NY. vol 16(6): 707-715. https://doi.org/10.1007/s10126-0149585-9.

Větrovský T, Baldrian P. 2013. The Variability of the 16S rRNA Gene in Bacterial Genomes and Its Consequences for Bacterial Community Analyses. PloS ONE. vol 8(2): e57923. https://doi.org/10.1371/journal.pone.0057 $\underline{923}$.

Xi Z, Liu L, Davis CC. 2015. Genes with Minimal Phylogenetic Information are Problematic for Coalescent Analyses when Gene Tree Estimation is Biased. Molecular Phylogenetics and Evolution. vol 92: 63-71. http://dx.doi.org/10.1016/j.ympev.2015.0 $\underline{6.009}$. 